\title{
Constructing the Architect of the Italian Renaissance
}

\section{Desley Luscombe}

Many Renaissance treatises on architecture included an allegorical frontispiece that portrayed both the discipline and the purveyor of architecture as having attributes that were social, ethical and moral in purpose. While Alberti in his De re aedificatoria reinforced the importance of virtus for citizenry, these illustrations join the concept of virtus with that of disegno in the architect's attributes. ${ }^{1}$ Allegorical frontispieces took an understanding of the architect beyond the role of designer of buildings. As a model citizen with responsibility for the visual representations of a governed society, he was represented as capable of forming architectural space and imagery, designed and organised by a programme of invenzione that inscribed political intent able to be read in the context of the court. ${ }^{2}$ Biographical texts, written in the same period, emulated the representation of the architect in the allegorical illustrations and presented, through the adoption of key terms, an explanation of individual genius. This paper examines the participation of architectural treatises in establishing the ethical and moral values that were instrumental in figuring the architect as a professional ideal, an ideal, which in turn informed understandings of genius, or in the Latin, ingenium, in individuals.

The re-emergence, during the Italian Renaissance, of the term 'architect' from antiquity (Latin architector or Italian architetto) influenced interpretations of the architect's function. ${ }^{3}$ These interpretations were also influenced by the increasingly popular illustrated printed books that, in their frontispieces, gave a visible explanation of the architect's role in social governance. Such visualisations depended on the development of meaning through the narrative structure of allegory. Allegorical meanings developed both independently, in each component of the illustration, and in the combination of signifiers and compositional clues, to contribute to its narrative of meaning (cf. Martin, 1994: 320-365). To examine characteristics of sixteenth century concepts of the architect, this paper focuses on two frontispieces. The first is from Cosimo Bartoli's translation of Leon Battista Alberti's De re aedificatoria (1550 and 1989), ${ }^{4}$ and the second is from Daniele Barbaro's commentary and translation of Vitruvius' De architectura (1556, 1567 and 1997). ${ }^{5}$

What brings these two texts together is that both translators, rather than being architects, were part of the structures of political governance in their cities. Of particular interest in this context are the social virtues attributed to disegno in the figure of the architect which, significantly, cross from notions of ideal type to reflections of individual worth. Hence, they announce an interconnection between architecture and the social that is located in the origin of modern formations of the architectural.

To examine characteristics of individual worth or ingenium, two of the lives from Giorgio Vasari's Le vite de' più eccellenti pittori, scultori e architettori (first printed
I would like to thank Dr. Flavia Marcello, The American University in Rome and Dr. Martha Fattori, Professore di Storia della filosofia moderna all'Università di Roma "La Sapienza", Facoltà di Filosofia, for their help in translation of the Italian texts. Page numbers for Vasari, Giorgio. 1568. Le vite de piu eccellenti pittori scultori et architetti, italiani. Firenze: Giunti. Retrieved II, January, 2006 from http://biblio.cribecu.sns/lt/vasari/ consultazione/Vasari/ricerca.html

I See Glossary (Alberti 1988).

2 Invenzione were narratives explaining how specific allegorical figures and symbols developed political meaning and could be judged as relevant to their locale and purpose.

3 For a history of the re-emergence of the term "architect", see Pevsner (1942: 549-562), Hollingsworth (1984), Vagnetti (1980).

4 This edition held the title L'architettura di Leonbattista Alberti, tradotta in lingua fiorentina da Cosimo Bartoli, Gentilhuomo, \& Academico Fiorentino.

5 This edition was titled I deci libri dell'architettura di M. Vitruvio tradutti et commentati da monsignor Barbaro eletto Patriarca d'Aquileggia, printed in the volgare during 1556. 
6 By social I do not mean society as an aggregate of people. Rather the concept includes all forms of social interchange and the boundaries that distinguish the organization of these interchanges.

7 Vasari's original drawing is found at the Uffizi, Gabinetto Disegni e Stampe (V, 47a).

8 Charles Davis has recognised that Bartoli wrote an explanation of the invenzione of the frontispiece in Ragionamenti accademici Davis (1980: 127-99). Although, the dating of the Ragionamenti is 1567, Bryce suggests that it was during the early I550s that Bartoli recast the Dante lectures he had given during the I540s and which were later printed as the Ragionamenti Bryce (1983: 7I)

9 For a full analysis of the frontispiece see Luscombe (2004).

$10 \mathrm{Gli}$ antichi finsono che nascesse puramente dal cervello di Giove, senza essersi egli congiunto, ò con lunone ò con altro: \& la intesono per la virtu intellettiva volendo mostrare, che dal Profondo segreto della sapienzia di Dio, nascesse ogni sapienza, \& ogni intelletto puro, \& separato da ogni terrena feccia, ò spurcizia, dentro a gli animi de gli huomini. in 1550 by the Florentine printer Lorenzo Torrentino, and then in 1568 by the Giunti printing house) will serve as points of reference. A study of the social virtues, developed in association with frontispieces, will show how these same virtues were considered in the individual. Such correlations would indicate that individual architects were represented as exemplars of citizenry-examples of the idealised or model citizen - within a notion of the social that was ordered and structured for political purposes. ${ }^{6}$

\section{The attributes of disegno as having the virtues of Minerva and Flora for Cosimo Bartoli and Giorgio Vasari's “Architect”.}

The frontispiece of Bartoli's translation L'architettura was designed by Vasari to an invenzione by Bartoli. ${ }^{7}$ Bartoli and Vasari were members of the socio-politically distinctive Florentine court of Cosimo I de'Medici (1519-1574). Bartoli's invenzione, reinforced through Vasari's design for the frontispiece, brings together the components of an idealised understanding of the architect contextualised by the Florentine court life of Cosimo I de'Medici (Bartoli, 1567: fol. 22-26r). ${ }^{8}$ In order to delimit the argument, the focus will be on the figures of Minerva and Flora, the prominent allegorical figures of the frontispiece. ${ }^{9}$ The reasons why specific virtues were assigned to the architect, and why his capacity of disegno was emphasized, can be gleaned from the illustrations' narratives and their combination of particular elements.

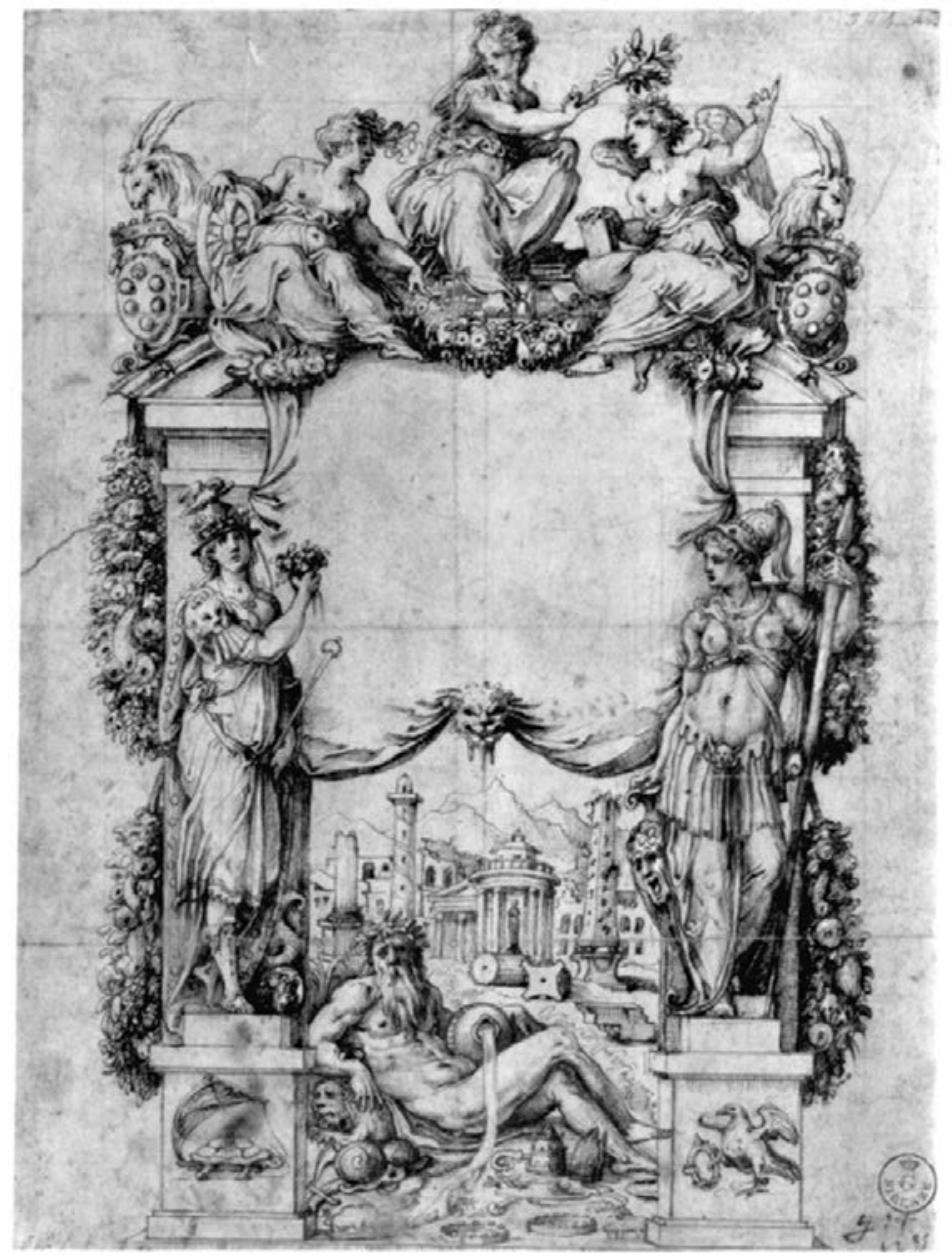


In Bartoli's invenzione, Minerva, the personification on the left of the aedicule, is described as the Wisdom of pure intellect. Bartoli explains:

the Ancients supposed that she was born purely from the brain of Jove, without having copulated, either with Juno or with another; and they intended her for intellectual virtue wanting to demonstrate that from the deep secret of God's wisdom, is born all wisdom, and each pure intellect, and separated from every earthly dreg, or filth, in the souls of men (Bartoli, 1567: fol. $23^{\mathrm{v}} .^{10}$

However, Bartoli also had the figure portraying the characteristics of Prudenza, the practical intellect of disegno, through her military attire and her attributes of physical valour. The concept of disegno encapsulated the capacity to represent the city, in all its forms, as a corporeal representation of governance corresponding to a metaphysical ideal. For Bartoli, the notion that art and architecture coexisted in two worlds, the divine and the corporeal, paralleled the notion that architectural creativity, although reflecting Divine creativity, derived from the architect's power to transform the idea, through disegno, into the social space of architecture. The architect's productivity was a physical enactment of the transference of beauty from an abstract principle to matter. For Bartoli, Minerva's attributes were essential in defining architecture as a higher order of intellectual activity related to civic governance.

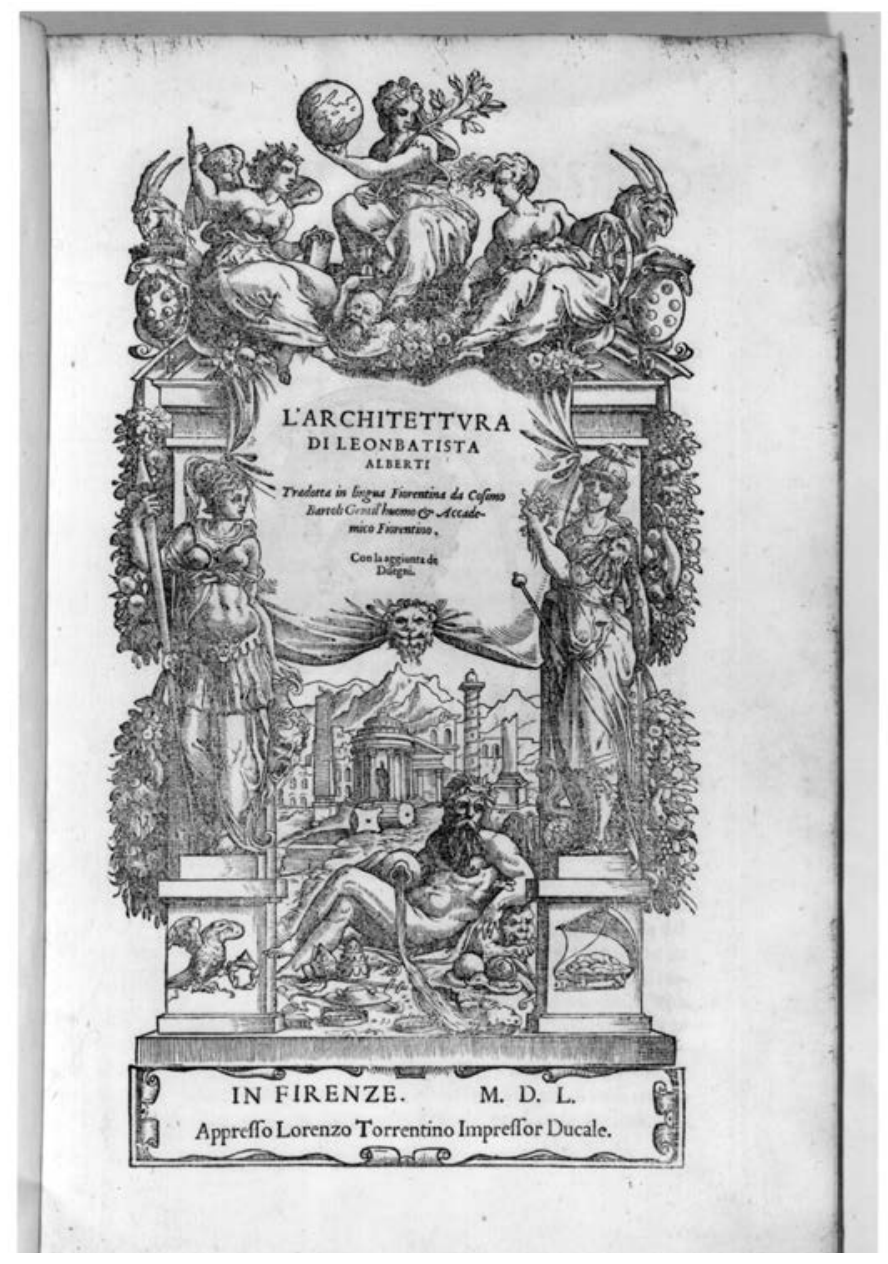

Giorgio Vasari and Cosimo Bartoli, Fontispiece 
II Wind's interpretation of Botticelli's image suggests that in the painting Primavera is in the act of transforming from one state of being to another. In Botticelli's painting, she is depicted fleeing Chastity (Chloris) and changing into Beauty (Flora) by the impact of Passion in the character of Zephyr, Wind (1958: 105).

12 For his explanation of idea see Panofsky (c1968). See also Summers analysis of disegno in sixteenthcentury Florence which calls attention to the attitudes of Federico Zuccaro who formulated the importance of this concept for architecture (1987: 298ff).
Bartoli continues his invenzione to describe and explain the personification of Flora, placed opposite Minerva. It is through Flora that the physical making of architecture is placed in dialogue with the virtues of intellectual capacity. Like Minerva, Bartoli imbues Flora with attributes of physical valour and action. But he also brings her into play to symbolise the city of Florence (Bartoli, 1567: fol. 24) ${ }^{\mathrm{v}}$ and to invoke her metaphysical persona Primavera. This is consistent with more traditional interpretations of Flora, where Primavera combines the physical attributes of spring's regeneration and the blossoming of flowers, as in the famous Sandro Botticelli painting Primavera (c. 1482). Even though painted approximately seventy years prior to the frontispiece, the painting's symbolism would have been well known to Bartoli and Vasari as it was housed in the Medici collection in Florence. $^{11}$

In the frontispiece, Flora has all the sensual attributes of worldly experience in the craft of making, whereas Minerva represents the Wisdom of the intellect that is distinct from, but still guided by, phenomenal experiences. Sensual and intellectual attributes are articulated in the image of the aedicule framing the personifications. In combination, Flora and Minerva describe the architect's capacity for disegno, bringing together concepts defining architecture as real form and as idea, and rendering his art invaluable to political governance of the city. ${ }^{12}$ Disegno, through drawing organised by geometry and proportion, transposed an image of ideal things into the real world - as architectural shapes. In a similar manner, through the combination of Minerva and Flora, Bartoli recognised the necessity for the intellect to be able to understand the sensible for what it is, in its state of transformation of an idea, while being located in the political structures of the city. Bartoli's vision is that these concepts are made useful to their specific social setting through the architect's understanding of purpose: his civic role.

Piero de'Medici's (1416-1469) imprese of the falcon and ring is placed below Minerva. Piero was the last direct heir of Cosimo de'Medici (1389-1464), the Pater Patriae of the lineage who was politically without blemish. Cosimo I de'Medici was related to Piero through his mother, and Piero's imprese provided a legitimacy that Cosimo needed to assert in claiming the title of Grand Duke of Tuscany. Cosimo I's own imprese of the tortoise and sail is placed below Flora in a position reinforcing his importance. These two arms of the Medici lineage culminate in the figure of Immortalità sitting in the pediment of the aedicule, holding the double-forked laurel, imprese of Cosimo I de'Medici, signifying the bringing together of the two strands of the family's genealogy. Furthermore, Immortalità forms an axis with the image of the river-god Arno below, surrounded by the many achievements in Florentine arts, framed symbolically by the aedicule signifying its architectural achievements. By depicting Minerva and Flora in this context, illustrating the power of the architect to enact politically relevant disegno for the Medici court, the frontispiece locates the architect as central to the requirement to form tangible representations of social governance in the city. The frontispiece to this 1550 edition of Alberti's text locates an affirmation of the role of the architect to represent, specifically for Florentine society, the important aspects of court culture and its hierarchy of power. 


\section{The attributes of disegno as the embodiment of practical intellectual habit in Daniele Barbaro and Andrea Palladio's "Architect"}

Andrea Palladio's design for Daniele Barbaro's frontispiece to I deci libri dell'architettura di M. Vitruvio used a triumphal arch to locate allegorical personifications and the title of the book. The invenzione for the design probably derives from Barbaro's proemio or foreword to the text. Building on the interpretation of the virtues associated with disegno in Bartoli and Vasari's 1550 frontispiece, my focus on Barbaro and Palladio's frontispiece will be on the two personifications in the niche of the triumphal arch.

When the figures are seen in relation to Barbaro's proemio, the qualities of Scienza described in the text become evident in the personification with attributes of Temperànza, in the left niche. The qualities of Intelletto can be seen in the figure on the right that includes attributes of Prudenza. ${ }^{13}$ This separation of virtues is distinctive when compared to those found in Bartoli's frontispiece, as the personifications articulate a more rigorously consistent division of attributes. Of the other five personifications of the Barbaro frontispiece, the four across the attic level of the arch represent the quadrivium of the arts: Geometria, Musica, Astrologia and Aritmetica. The central figure is a representation of the virtue of rational wisdom in the figure of Sapiènza. ${ }^{14}$

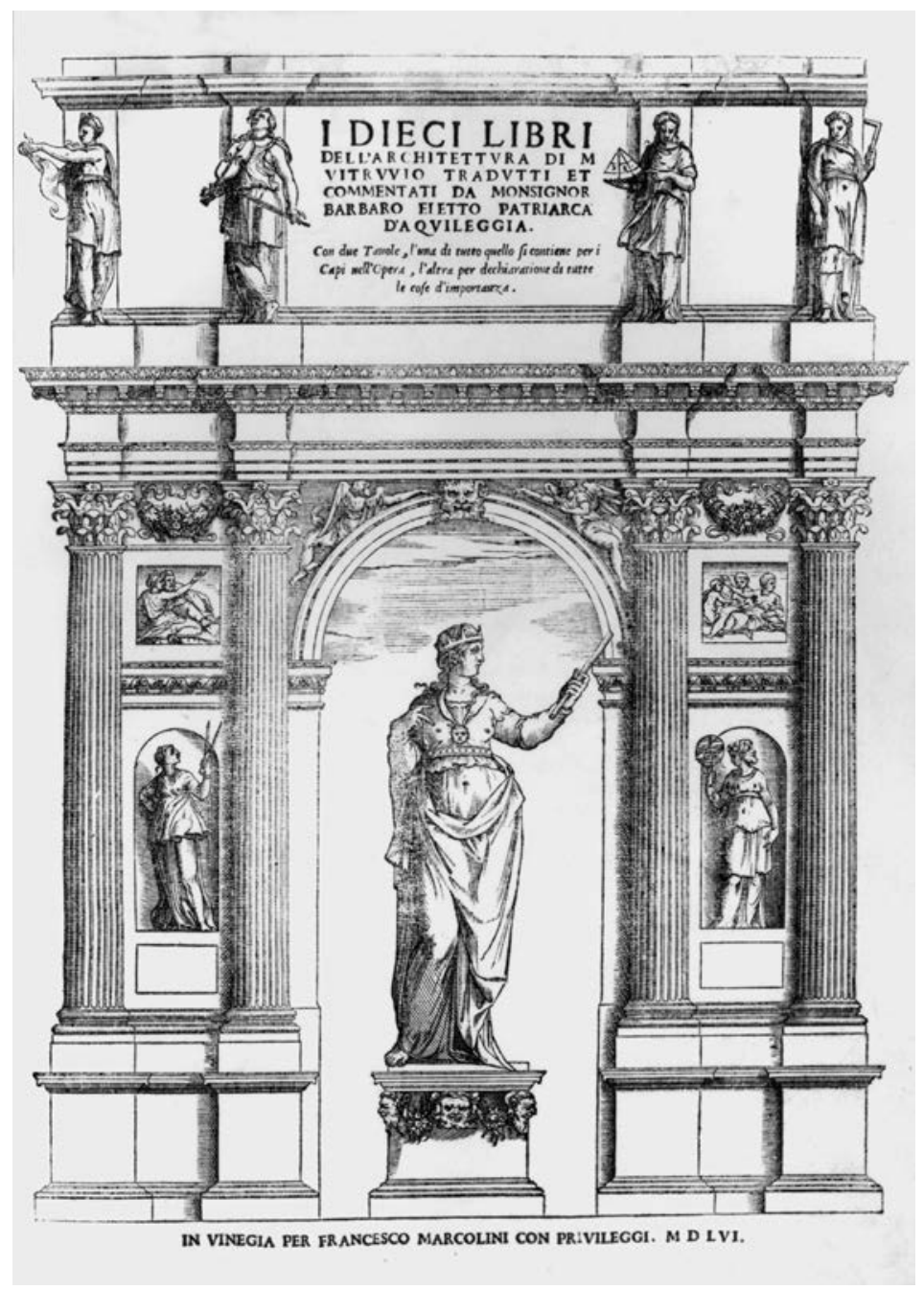

3 In past interpretations of the frontispiece, the figure in the left niche has been attributed the name of either Theory or Astrology. The figure on the right has been interpreted as Practice, Experientia or Prudenza, Frascari (1988: 15-27), Angelini (1999), and Miotto (1999: 233-243).

14 I disagree with Miotto's interpretation of these as 'Rhetoric,' 'Music,' 'Arithmetic,' and 'Geometry.' See Luscombe (2004).
Frontispice, Andrea Palladio and Daniele Barbaro, I deci libri dell' architectura di M. Vitruvio tradutti et commentati da monsignor Barbaro eletto Patriarca d'Aquileggia, Venezia: Marcolini, 1556, Montreal, Centre Canadien d'Architecturel Canadian Centre for Architecture 
I5 La prima e nominata Scienza, che habito è di conclusione per vera \& necessaria prova.
In his proemio to the first book of Vitruvius, Barbaro introduced the term habitus to explain the workings of the intellect. The term habitus has an Aristotelian source and refers to the actions emanating "from an acquired perfect state or condition" (Calabi and Morachiello, 1987: 231). Barbaro followed Benedetto Varchi's Due lezzioni for his use of the term and separated habits stemming from "necessary truth ... composed of the proof of the thing proven", from those emanating from "contingent truth" that are dependent on will. Both writers place art within the category of contingent truth (Barbaro, 1556: 6; 1567: 2-3). Varchi had correlated the human soul with a notion of Reason, which was then divided into distinctive categories of particular reason and universal reason. Within his understanding of universal reason, he separated inferior reason from superior reason - associating the habit of science with superior reason and the habit of art with inferior reason, because art culminated in making whereas science was culmination in knowledge. Art was thus the lowest habit of human reason (cf. Summers, 1987: 276ff; Mendelsohn, 1982: 6-9). Nevertheless, Barbaro suggested a link between Architettura and "necessary truth" related to higher categories of reason, due to its reliance on Geometria, Aritmetica and the other sciences of the quadrivium. Further, Barbaro argued that Architettura was synonymous with rhetoric, a higher habit of Reason (Barbaro in Vitruvius, 1567: 36).

The personifications of Scienza and Intelletto were developed by Barbaro to make Vitruvius' Roman first-century BCE text relevant to sixteenth-century Italian contexts and concerns with intellect and reason. Scienza, on the left, incorporates attributes of Temperànza and is represented as a gaunt old woman clothed in full robes with her head covered. Scienza is looking upward and raises opened compasses high in her left hand. This directional orientation suggests an association with the quadrivium on the attic level. Vincenzo Fontana claims that in an earlier manuscript, Libro detto delle quattro porte, Barbaro had suggested that Aritmetica, Musica, Geometria and Astrologia as the quadrivium constituted the four doorways to knowledge (Fontana, 1985: 39-72). The quadrivium was, indeed, fundamental to divisions of knowledge in Architettura. For Barbaro, as for Varchi, Scienza was associated with "necessary truth" and the rational logic of proof in its subject, as distinct from the contingencies of phenomena. Barbaro notes in his proemio that Scienza "is a conclusion acquired through true and necessary proof" (in Vitruvius, 1556: 6). ${ }^{15}$ Scienza provides Barbaro with a link between Architecture and "necessary truth" through her gaze toward Geometria and Aritmetica.

Temperànza's association with the figure of Scienza, as a virtue of the architect, suggested a need to possess objective rationality in order to restrain acts of personal licence. The set of compasses Scienza is holding symbolise the architect's comprehension, through their use, of the principles of geometry and mathematics, which enable him to form judgments about his art. In this context, Temperànza warns the architect that he should not presume that all of his discoveries will necessarily reflect philosophic principles related to the rational logic of proofs. Consistent with Alberti, Barbaro believed that the architect should lead an active political life and work for the benefit of the whole of society. For Barbaro, the architect's Temperànza is an attribute that allows him to recognise principles. Through disegno, it leads to an appreciation that architecture reflects principle and idea. Rational wisdom, in this case, is associated with practical reasoning. Truth, for the architect, is about making distinct, through his combination of Intelletto with Prudenza, ideas of practical reasoning. 
The figure in the right hand niche is Intelletto. In his proemio Barbaro noted that Intelletto, while also about principles and proofs, "retains the name of the power of the soul where it is found" (in Vitruvius, 1556: 6).${ }^{16}$ Intelletto is portrayed as a fully clothed young woman looking downward, with the back of her head forming a second face, that of an old man. ${ }^{17}$ Her youthful face gazes into an armillary sphere she holds, whereas the face of the old man gazes toward the edge of the frontispiece. This Janus like configuration goes back to older representations of Prudenza whose youthful face, traditionally often portrayed as looking into a mirror, symbolised self-knowledge and virtue, while her old face represented the wisdom gained through historical distance. The mirror is replaced in Barbaro and Palladio's representation of Intelletto by a speculum nature (mirror of nature) in an armillary sphere. This suggests that in Barbaro's conceptualisation of the architect, Intelletto inferred the self-knowledge of Natura and principles of natural cause. ${ }^{18}$ Annarita Angelini suggests that the motif of the downward and upward gazes of Intelletto's faces and its source in Prudenza give each figure the double meaning of universal theory and earth bound action (Angelini, 1999: 18ff; see also Miotto, 1999: 233-243). Characterised in this way, Intelletto reflects the two-fold ability of the architect to build buildings and to conceptualise natural philosophy through his practices. ${ }^{19}$ For Barbaro, Intelletto calls attention to the differences between, as well as interrelatedness of, causes or first principles in the context of their operational use, through the architect's capacity for disegno, in the service of men. ${ }^{20}$ Unlike in Bartoli's frontispiece, where Flora's attributes illustrate the transformation of the idea through the act of making and the architect's disegno, Barbaro reinforces disegno by associating it with the self-knowledge and principles of Natura. Thus, by placing Scienza opposite Intelletto to emphasize the primary role of the concept of disegno for the architect, Barbaro combines the requirement of rational principles and those of social good in the practices of the architect.

The classical framing of the frontispiece to Barbaro's translation and commentary with a triumphal arch setting is unmistakably based on an earlier sketch by Palladio for his competition entry for the Rialto Bridge project of $1554 .{ }^{21}$ The illustration's technique, with its orthographic projection, reflects Barbaro's conception of Architettura as the highest of the arts. It depicts the power of the architect's capacity for disegno as it moves from idea to real form in its measurable precision and accurate portrayal of geometric proportion. Barbaro's allusion to the importance of the orthographic projection to disegno is further reinforced by the figure of Sapienza, or rational wisdom. She holds a measuring rod, pointing at the appreciable accuracy of a drawing of the triumphal arch. The manifestation of Sapienza in Architettura conferred to the architect the virtue of judgment, informed by intellectual wisdom and knowledge, alongside the agility of Scienza and Intelletto.

In defining the architect's attributes as a social figure in the context of sixteenth century thinking, Cosimo Bartoli and Daniele Barbaro elaborated the architect's intellect as ideal action, in the formulation of propositions for real form. Both writers saw the ideal architect as actively engaged in political life, working for the good of society. Through a capacity for disegno and the ability to make - structuring building campaigns to create social space through architecture - the architect was idealised as a type. When we compare the characteristics of the ideal 'architect' emerging in these representations with those in biographical texts, it
16 La seconda è detta Intelletto, che è habito de i principij, \& delle prove, \& ritiene il nome della potenza dell'anima, della quale egli si truova ....

17 Both Frascari (1988) and Miotto (1999) have considered the figure as 'Prudence' because of her two faces.

I8 Cf. Frascari (1988: 22) suggestion of a possible source being the tarot card set by Andrea Mantegna where his representation of Prudencia holds a speculum showing her reflection.

19 For discussion of the Aristotelian interpretation of Prudenza and Intelletto, Summers (1987: 273ff).

20 Barbaro in Vitruvius (1556: 6). La seconda è detta Intelletto, che è habito de i principij, \& delle prove, \& ritiene il nome della potenza dell'anima, della quale egli si truova: la onde è nominato, Intelletto.

2I See Burns (1973), Gioseffi (1973) and Calabi (1987) for their discussion of the competition entry. 
Andrea Palladio, Rialto Bridge PRoject, Ink drawing, Museo Civico, Vicenca

22 Vasari's involvement with the establishment of the Academic del Disegno, and his discussion of disegno in his technical preface provide a context for his advocacy of the central role of the architect. See discussion Rubin (1995: 234ff.).

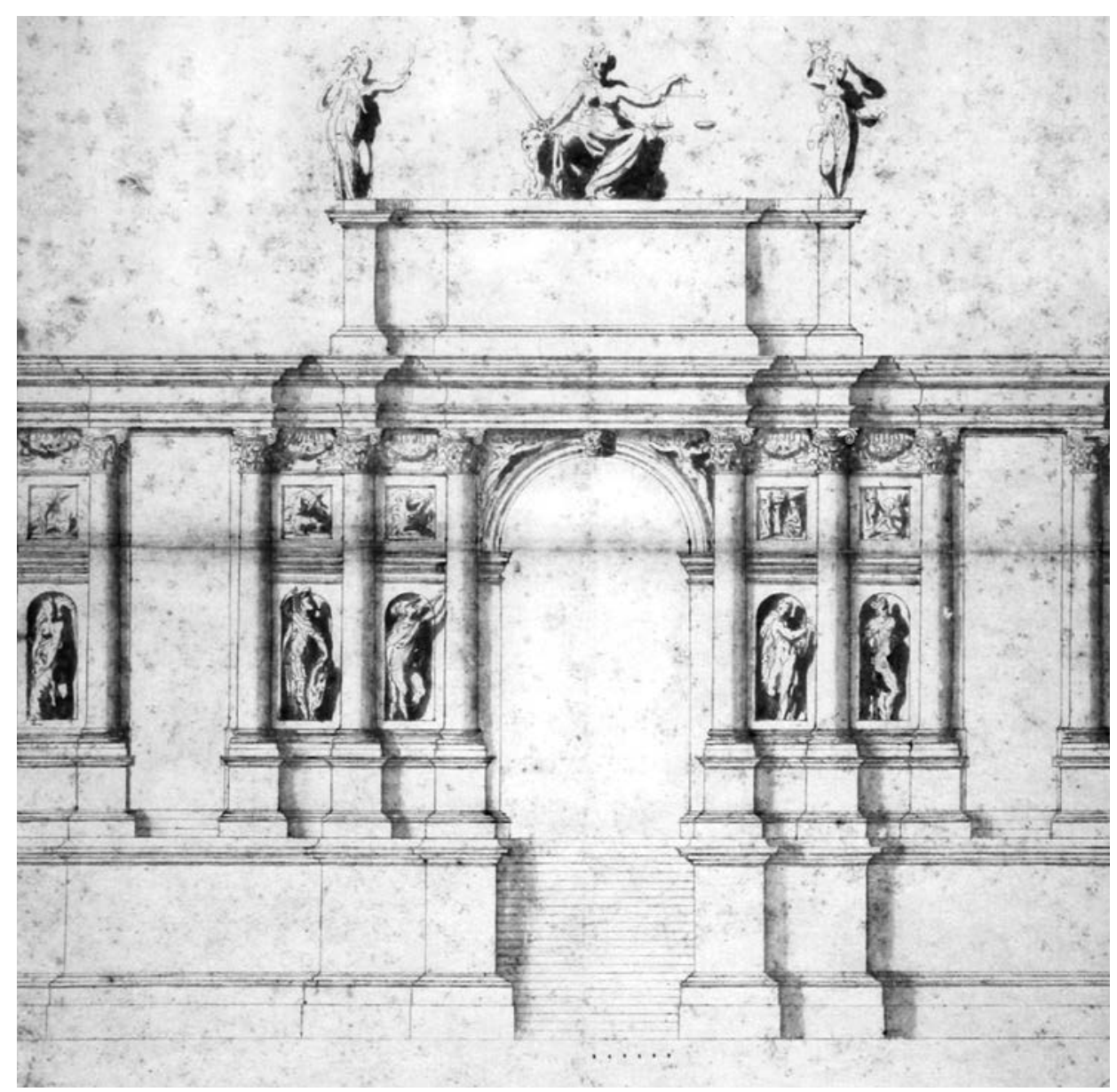

will become apparent that attributes referring to social functions in the former are used in the latter to signify individual worth. As a result, some individual architects were conceived, distinct from their artistic practices, as model citizens, within a conception of a society ordered and structured for political purpose.

\section{The attributes of genius (ingenium) in Vasari's Vite.}

Vasari's Le vite de' più eccellenti pittori, scultori e architettori established the value of individual architects' works based on a correspondence with the virtues of the idealised architect. ${ }^{22}$ Rather than relying on the structure of allegorical divisions found in the frontispieces, Vasari explained through individual examples how virtuous acts, or the culmination of virtues in the individual, could determine beauty in art and achieve in real form what he called divine or natural perfection. In examining the attributes of Minerva as rational wisdom and Scienza informed by Temperànza for their similarity to descriptions in Vasari's writing, I will focus on his account of the lives of Michelangelo and Brunelleschi.

In a similar manner to Bartoli and Barbaro, an essential component of Vasari's concept of the architect's worth is his belief that architecture develops in the intellect as a mediated transference of idea to real form. Consistent with the concept of disegno in the frontispieces, Vasari distinguished architecture from the manual skills 
gained through the experience of repetitive manual practices, to characterize it as a higher form of knowledge. Like Bartoli, Vasari saw the architect's intellect aligned with rational wisdom (Minerva) informed by Prudenza. Barbaro's more Aristotelian understanding of the architect had presented Scienza as an attribute distinct from practical intellect (Intelletto informed by Prudenza), whereas Bartoli and Vasari both suggested that it is the practical intellect of the architect that is his highest virtue. For Bartoli, Vasari, and Barbaro, Prudenza was an intellectual habit that emanated from a pre-disposed moral virtue in the good citizen, resulting in an individual architect's ability to realise "natural philosophy in practice" (Summers, 1987: 275). However, it was only Barbaro who valued Scienza as qualifying a distinct form of an architect's intellectual practice, his comprehension of the power of principle.

Vasari continuously made references to Michelangelo's honour and moral prudence. To establish consistency between the notions of individual and idealised Architect, he employed Michelangelo's appeal that the architect should have his compasses in his eyes, a metaphor for grasping Divine order through the intellect. ${ }^{23}$ In a statement that resembles Cosimo Bartoli's invenzione, Vasari wrote about Michelangelo:

It is known that when he wanted to extract Minerva from the head of Jove it was necessary for him to use Vulcan's hammer ... he said that it was necessary to hold one's intruments in the eye and not in the hand because it is the hands that work but the eye that judges: and this is the method he used in architecture as well (Vasari, 1996: 773-774; 1568: 109). ${ }^{24}$

This connection between the mind and the eye are the requirements of disegno in Bartoli's notion of the architect. Vasari constructs Michelangelo as the genius architect who is able to be the living incarnation of the idea of Minerva.

Continuing, Vasari reinforces a notion in Bartoli and Barbaro's concept of the architect, namely, that genius cannot simply reside in an act of contemplation and study but that, for the architect, it requires an active and informed engagement with the decorum expected of public figures, through Prudenza and Temperànza. Reinforcing Barbaro's association between Scienza and Temperànza, Vasari writes about Michelangelo's individual mannerisms, "He greatly loved human beauty for the sake of imitation in art ... for without this imitation no perfect work can be done; but not with lascivious and disgraceful thoughts as he proved by his way of life, which was very frugal" (Vasari, 1996: 739; 1568: 112). ${ }^{25}$ Here, Vasari associates notions of "necessary truth", a quality of Scienza found in the idealised architect through "imitation", with Temperànza in individual architects.

Vasari conflated, as did Bartoli, the distinct notions of rational intellect (Scienza) and practical intellect (Intelletto). Separating them from the notion of making, he was able to argue that specific experiences in practice and life had lead to the development of ingegno in the architect. Mirroring the concept of disegno in art, this transformation of character through experience for Vasari turned into a measure of recognising worth in architecture, as well as in an individual architect's character; an emblem in the architect's life as well as in his work.
23 Clements (1961: 31) has discovered four texts testifying that Michelangelo's saying had a meaning commonly understood in Florence.

24 Vasari (1996: 773-774; I568: 109)...si conosce, che quando e' voleva cavar Minerva dalla testa di Giove, ci bisognava il Martello di Vulcano: imperò egli usò le sue figure e farle di 9 \& di 10 \& di 12 teste, non cercando altro che col metterle tutte insieme ci fussi una certa concordanza di gratia nel tutto, che non lo fa naturale, dicendo che bisoganava avere le seste negli occhi, \& non in mano, perche le mani operano, et l'occhio giudica: che tale modo tenne ancora nell'architettura.

25 Vasari (1996: 739; 1568: II2) Amò grandemente le bellezze umane per la imitazione dell'arte, per potere scierre il bello dal bello, ché senza questa imitazione non si può far cosa perfetta: ma non in pensieri lascivi e disonesti, che l'ha mostro nel modo del viver suo, che è stato parchissimo. 
26 Vasari (1996: 354; 1568: 187) In tanto artifizioso, che non si può imaginar piu bella, ne piu magnifica Architettura.
In his account of the life of Brunelleschi, for example, Vasari argued that, even though Brunelleschi was not a man of letters, he was able to achieve greatness because of his ability for mathematics, together with a great deal of practice and experience. However, Vasari then continued that it was only after Brunelleschi became a man of letters that he was able to create a building which, "in its very artifice, you cannot imagine more beautiful, nor more magnificent Architecture" (1996: 354; 1568: 187). ${ }^{26}$ Vasari's use of a transformation in Brunelleschi's development as an architect to promote recognition of the value of his work parallels Bartoli's understanding of Flora's attributes.

These virtues were not only used to define the architect as a model citizen with responsibility for the visual representations of a governed society. They were also used to assert an understanding of individual genius, which indicates a desire to consolidate diverging perceptions of social order within the city's representation as a governed society. Each occasion used to display the good citizenry of individual architects, through recognition of moral and ethical virtues in their practices, served to reinforce the formation of a collective abstract and ideal type that could transform into the notion of a profession.

Later transformations of this idealised type of social figure into the notion of a profession could be easily achieved. Thus, the moral and ethical virtues used to idealise the figure of the architect, distinctively understood in Italy as a profession, came to be synonymous with descriptions of the individuals taking part in this profession's practices. In this context, Vasari's claims for determining genius and worth amongst specific architects not only set them apart from the mass of citizens but raised their status as exempla for good citizenry.

\section{References}

Alberti, L. B. (1550). L'Architettura di Leonbatista Alberti tradotta in lingua fiorentina da Cosimo Bartoli con la aggiunta de designi. Firenze: Appresso Lorenzo Torrentino.

Alberti, L. B. (1988). On The Art of Building in Ten Books (Joseph Rykwert, Neil Leach and Robert Tavenor, Trans.). Cambridge (Mass.): MIT Press.

Angelini, A. (1999). Sapienza prudenzia eroica virtù: Il mediomondo di Danile Barbaro. Firenze: Olschki.

Bartoli, C. (1567). Ragionamenti accademici di Cosimo Bartoli Gentil'huomo et Accademico Fiorentino, sopra alcuni luoghi difficili di Dante Con alcune inventioni et significati, et la Tavola di più cose notabili. Venezia: Francesco de Franceschi Senese.

Bryce, Judith. (1983). Cosimo Bartoli: The Career of a Florentine Polymath. Geneve: Librarie Droz.

Burns, Howard. (1973). I disegni del Palladio. Bollettino del Centro Internazionale Studi sull'Architettura, A Palladio (XV), 169-191.

Calabi, D., \& Paolo M. (1987). Rialto: le fabbriche e il ponte, 1514-1591. Torino: Einaudi.

Clements, R. (1961). Michelangelo's Theory of Art. London: Routledge \& Kegan Paul.

Davis, C. (1980). Frescos by Vasari for Sforza Almeni, coppiere to Duke Cosimo I. Mitteilungen des Kunsthistorischen Institutes in Florenz (14), 127-99.

Fontana, V. (1985). Il 'Vitruvio' dell 1556: Barbaro, Palladio, Marcolini. In E. Riondato (Ed.). Trat- 
tati Scientifico nel Veneto fra il XV e XVI secolo. Venezia: Università Internationale dell'Arte, 39-72.

Frascari, M. (1988). Maidens 'Theory' and 'Practice'. Assemblage (7, October), 15-27.

Gioseffi, D. (1973). Palladio e l'antichita. Bolletino del Centro Internazionale di Studi di'Architettura, Andrea Palladio (15), 43-65.

Hollingsworth, M. (1984). The Architect in Fifteenth-Century Florence. Art History (7, December), 385-410.

Lewis, D. (1981). The Drawings of Andrea Palladio. Washington: International Exhibitions Foundation.

Luscombe, D. (2004). Inscribing the Architect: The Depiction of the Attributes of the Architect in Frontispieces to Sixteenth Century Italian Architectural Treatises. Unpublished dissertation for the Degree of Doctor of Philosophy, University of New South Wales.

Martin, H-J. (1994). The History and Power of Writing. Chicago: University of Chicago Press.

Mendelsohn, L. (1982). Paragoni: Benedetto Varchi's "Due lezzioni" and Cinquecento Art Theory. Ann Arbor (Mi.): UMI Research Press.

Miotto, L. (1999). Le Vitruve traduit, commenté et illustré de Daniele Barbaro (1556). In M. Plaisance (Ed.), Le livre illustré italien au XVI e siècle (pp. 233-243). Klincksieck: Presses de la Sorbonne Nouvelle.

Panofsky, E. (c1968). Idea: a concept in art theory (J. Peake Trans.). New York: Harper \& Row.

Pevsner, N. (1942). The Term Architect in the Middle Ages. Speculum (XVII), 549-562.

Rubin, P. (1995). Giorgio Vasari Art and History. New Haven: Yale UP.

Summers, D. (1987). The Judgment of Sense, Renaissance Naturalism and the Rise of Aesthetics. Cambridge: Cambridge UP.

Vagnetti, L. (1980). L'architetto nella storia di Occidente. Padua: CEDAM.

Vasari, G. (1550). Le vite de' più eccellenti pittori, scultori e architettori. Firenze: Torrentino.

Vasari, G. (1568). Le vite de' più eccellenti pittori, scultori e architettori. Firenze: Giunti.

Vitruvius. (1556). I deci libri dell'architettura di M. Vitruvio tradutti et commentati da monsignor Barbaro eletto Patriarca d'Aquileggia (D. Barbaro Trans. and Ed.). Venezia: Francesco Marcolini.

Vitruvius. (1997). I dieci libri dell'architettura, tradotti e commentati da Daniele Barbaro. Tafuri, M. \& Morresi, M. (Eds.). Milano: Polifilo. (Facsimile edition of Vitruvius 1567).

Wind, E. (1958). Pagan Mysteries in the Renaissance. London: Faber and Faber 